An investigation was aimed at possibly eliminating the excess oxygen uptake. Several inhibitors were tested for their capacity to diminish specifically the oxygen uptake, but these experiments will be published separately. It is sufficient for the present argument to note that in experiments overlapping those of Creasey ${ }^{10}$ there was essential agreement : precise addition of selected inhibitors may force the oxygen uptake almost to obey stoichiometry.

In conclusion, it seems obvious that the techniques for determining ammonia ${ }^{3,5,7}$ would provide a more specific yardstick for the monoaminoxidase activity of tissues than does the popular respirometry. The latter may be coached to yield almost stoichiometric results, but the necessary chemical tour de force produces a complex and rigid system.

This work was supported by the U.S. Atomic Energy Commission.

George C. Cotzias

James J. GremnoUgh

Medical Research Center,

Brookhaven National Laboratory, Upton, New York. March 12.

${ }^{2}$ Bogdanski, D. F., and Udenfriend, S., J. Pharmacol and Exp. Therap., 116,7 (1956). Broadie, B. B., Pietsher, A., and Shore, man, R., and Shore, P. A., ibid., 119,461 (1957).

${ }^{2}$ Davison, A. N., Physiol. Rev., 38, 729 (1958).

${ }^{3}$ Cotzias, G. C., and Dole, V. P., J. Biol. Chem., 190, 665 (1951)

- Cotzias, G. C., and Dole, V. P., Proc. Soc. Exp. Biol. and Med., 78, 157 (1951).

${ }^{6}$ Cotzias, G. C., and Dole, V. P., J. Biol. Chem., 198, 235 (1952).

${ }^{8}$ Cotzias, G. C., Serlin, I., and Greenough, J. J., Science, 120, 114 (1953).

'Cotzias, G. C., and Greenough, J. J., Arch. Biochem. Biophys., 75, 15 1958).

8 Blaschko, H., Pharmacol. Rev., 4, 415 (1952).

- Hawkins, J., Biochem. J., 50, 577 (1952).

${ }^{10}$ Creasey, N. H., Biochem. J., 64, 178 (1956)

\section{A Rare Variant of B in a Human Blood Sample belonging to Group $A B$}

DuRING routine blood-group examination of healthy persons, one of the blood samples tested was found to exhibit unusual properties. The potent anti-A and anti-B test sera used agglutinated the erythrocytes quite well, whereas the serum of this $A B$ blood (subgroup $A_{2} B$ ) reacted weakly at room temperature with $B$ cells. The irregular agglutinin was no more active at $37^{\circ} \mathrm{C}$. and reacted better at $4^{\circ} \mathrm{C}$. (titro 8 ) than at $20^{\circ} \mathrm{C}$. No auto-agglutination was observed. At $4^{\circ} \mathrm{C}$. the serum agglutinated all of $15 \mathrm{~B}$ but neither 20 A nor 150 cells samples simultaneously tested. The B specificity of this agglutinin was confirmed by absorption experiments with B erythrocytes and with purified blood group B substance. The B specificity of the agglutinogen in Mrs. Br.'s cells was ascertained by studying the action of several $A$ and $A B$ sera on them; the agglutinating action of A sera did not occur after absorption by normal B cells or purified B substance. The 'Br.' cells significantly absorbed the anti-B agglutinin in normal A sera, but less, however, than did $\mathrm{A}_{2} \mathrm{~B}$ cells used as control, and released it after elution more completely than did these $\mathrm{A}_{2} \mathrm{~B}$ cells. The 'Br.' cells were agglutinated by anti- $\mathrm{H}$ eel serum nearly as well as group $\mathrm{O}$ cells. The 'Br.' saliva inhibited the anti-A agglutinin at a high dilution, and the anti- $\mathrm{B}$ and anti- $\mathrm{H}$ agglutinins when more concentrated. Its inhibitory action on anti-H was not weaker than that of an $\mathbf{A}_{2}$ control

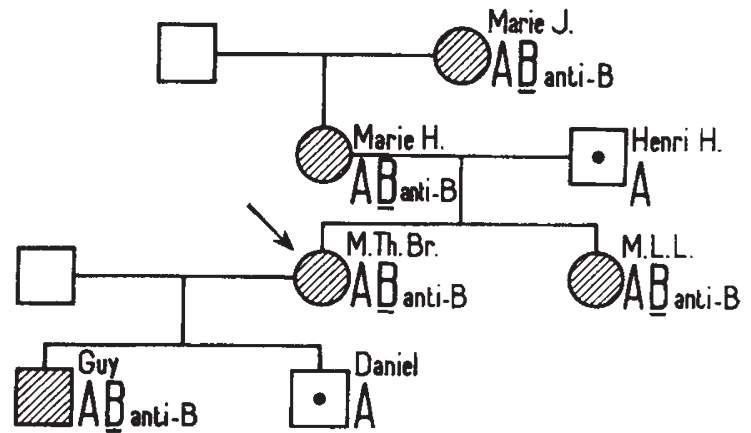

Fig. 1

This unusual subgroup was found in the blood of four other members of Mrs. Br.'s family. The four samples, belonging to the $\mathrm{AB}$ group, showed the same serological pattern as the 'Br.' blood. The irregular anti-B agglutinin was present in their serum, at a titre of 4 to 16 (at $4^{\circ}$ C.). The four samples of saliva contained $\mathrm{A}, \mathrm{B}$ and $\mathrm{H}$ substances but did not inhibit Mrs. Br.'s anti-B agglutinin.

The variant of $B$ here described is quite different from the recently published cases of very weak $B$ agglutinogens ${ }^{1-4}$. It would probably more likely resemble the case reported by Formaggio $^{5}$ (whose serum contained also an anti-B agglutinin) and perhaps those found in Pakistan by Boyd ${ }^{6}$. In considering its serological character, it appeared to us that it behaved in a way very similar to that of $\mathbf{A}_{2}$ within the A group.

\section{J. Moulled}

Centre National de Transfusion Sanguine, 6 rue Alexandre-Cabanel, Paris $15 \mathrm{e}$

Poste de Transfusion,

P. Le Chevret,

Vire, Calvados.

1 Mräkelä, O., and Mäkelä, P., Ann. Med. Exp. Fenn., 33, 33 (1955). ${ }^{2}$ Moullec, J., Sutton, E., and Burgada, M., Rev. Hématol., 10, 574 (1955).

${ }^{3}$ Levine, P., Celano, M., and (rriset, T., Sixth Congress Internat. Soc. Blood Transf., Boston, 132 (1956).

- Dunsford, I., Stacey, S. M., and Yokoyama, M., Nature, 178, 1167 (1956)

- Formaggio, T. G., Fourth Congr. Internat. Soc. Blood Transf., Lisbonne, 330 (1951).

${ }^{8}$ Boyd, W. C., Amer. J. Phys. Anthrop., 12, 393 (1954).

\section{Pressor Amines and Neuroblastoma}

Isaacs, Medalie and Politzer ${ }^{1}$ describe three cases of neuroblastoma in children in whom the 24-hr. excretion of noradrenaline in urine was 200-300 $\mu \mathrm{gm}$. This is not a vast amount but may be abnormally high. The suggestion was that neuroblastoma is a tumour which, like phæochromocytoma, secretes pressor amines. On March 23, 1959, I obtained, by courtesy of Dr. P. T. Bray, a specimen of tumour infiltrating the left kidney, taken by Mr. H. Wade from a boy aged nine years at East Glamorgan Hospital, Church Village, Glamorgan, and kept frozen. This tumour was reported by the histopathologist to be typical neuroblastoma; the whole specimen weighed approximately $450 \mathrm{gm}$. of which some $300 \mathrm{gm}$. was turnour. $50 \mathrm{gm}$. was excised from the region which had been used for histology, cut up fine and homogenized with $50 \mathrm{ml}$. of water containing $5 \mathrm{mgm}$. ascorbic acid. This was spun at 3,000 r.p.m. for $15 \mathrm{~min}$. and the supernatant examined on the blood pressure of the spinal rat in- 